\title{
Ergonomía y discapacidad
}

María Eugenia Figueroa

\section{Resumen}

Los nuevos conceptos de discapacidad enfatizan la relación entre las limitaciones de las personas y la estructura de su entorno.

La mayoría de los países han desarrollado normas para lograr la igualdad de participación de las personas con discapacidad, y Chile no es la excepción. Sin embargo, sabemos que se requiere más que normativas o leyes para lograr este objetivo, especialmente por las barreras presentes en la cuidad, espacios públicos y lugares de trabajo.

Esta publicación presenta a la Ergonomía, como un modelo pertinente para operacionalizar estos desafíos, ya que por su carácter centrado en las personas, reconoce la diversidad de los individuos y trabaja adaptando las exigencias de los entornos.

Con esta visión la Ergonomía puede abordar dos ámbitos fundamentales: la Accesibilidad y la Integración Laboral. Para el primero, se propone la aplicación del Diseño Universal, eliminando las barreras en el medio físico, sean: de carácter arquitectónico, urbanístico, de transporte o de telecomunicaciones, y en ámbito de la integración laboral, la Ergonomía, mediante el análisis ergonómico, desplaza la atención desde la persona al trabajo, descubriendo nuevas vías de solución y procurando que las exigencias del trabajo se adecúen a las capacidades de las personas con discapacidad.

\section{Abstract}

New concepts in dissability emphazyse the relation between persons with limitations and the structure of the enviroment.

Most of the countries have developed norms to gain equality for persons with dissabilities, and chile is not an exception. Nevertheless, we know that norms and laws are not enough to reach this goal, specially due to architectonical barriers in cities,public and work places.

This article presents Ergonomics as an appropiate model to accomplish this challenges, as it recognizes personal differences and works to adapt the enviroment to them.

From this view, Ergonomics can work with two basic concepts: accesibility and work integration. For the first, it proposes to apply the "Universal Design", suppressing barriers in physical enviroment wich can be architectonical, urbanistic, of transport or telecomunications. In work integration Ergonomics do ergonomical 
analysis, putting the accent on work, trying that its requirements cope with habilities of persons with dissabilities. 